\title{
GLYCOLYSIS IN THE BLOOD OF PATIENTS WITH PERNICIOUS ANEMIA
}

\author{
By S. MILTON GOLDHAMER \\ (From the Thomas Henry Simpson Memorial Institute for Medical Research, University \\ of Michigan, Ann Arbor)
}

(Received for publication February 7, 1933)

Following the discovery by Warburg that tumor cells have quantitative and qualitative differences from those of normal tissues with regard to their carbohydrate metabolism, many investigators have demonstrated that the method of glycolysis was most satisfactory for the study of the metabolism of the blood cells. Maclean and Weir (1) pointed out the role played by the different blood elements in glycolysis, and showed that the erythrocytes were a vital factor in the sugar consumption of normal blood. Inasmuch as the red blood cells play an important part in the glycolytic activity of normal blood, and since pernicious anemia is a disease primarily involving the red cells (both number and type), a study of the glycolysis of the blood in this malady has been undertaken for further investigation of the metabolism of the red cells.

\section{METHODS}

Blood sugar determinations were made from the blood of nine patients with pernicious anemia before treatment and at the height of the reticulocyte response, following ventriculin therapy. Red cell, white cell and reticulocyte counts were made on corresponding days.

The blood sugar values were calculated according to the micro-method of Folin and $\mathrm{Wu}(2)$. All the estimations were made from blood samples obtained before breakfast at 8 A.M. The usual procedure was to withdraw 10 to $15 \mathrm{cc}$. of blood from the arm vein under sterile precautions, no tourniquet being used in order to avoid stasis. The blood was discharged into a large test tube, mixed with heparin, and kept in a warm room at a temperature of $37^{\circ} \mathrm{C}$. Heparin was used as an anti-coagulant as it was shown by Falcon-Lesses (3) to have no appreciable effect on the rate of glycolysis.

The blood sugar content was determined immediately after the removal of the specimen from the patient, and then at hourly intervals for 5 hours to estimate the glycolytic activity. The red blood cell and white blood cell counts were made with U. S. Bureau of Standards pipettes and Neubauer-Levy counting chambers. Reticulocyte estimations were made from brilliant cresyl-blue film preparations. 


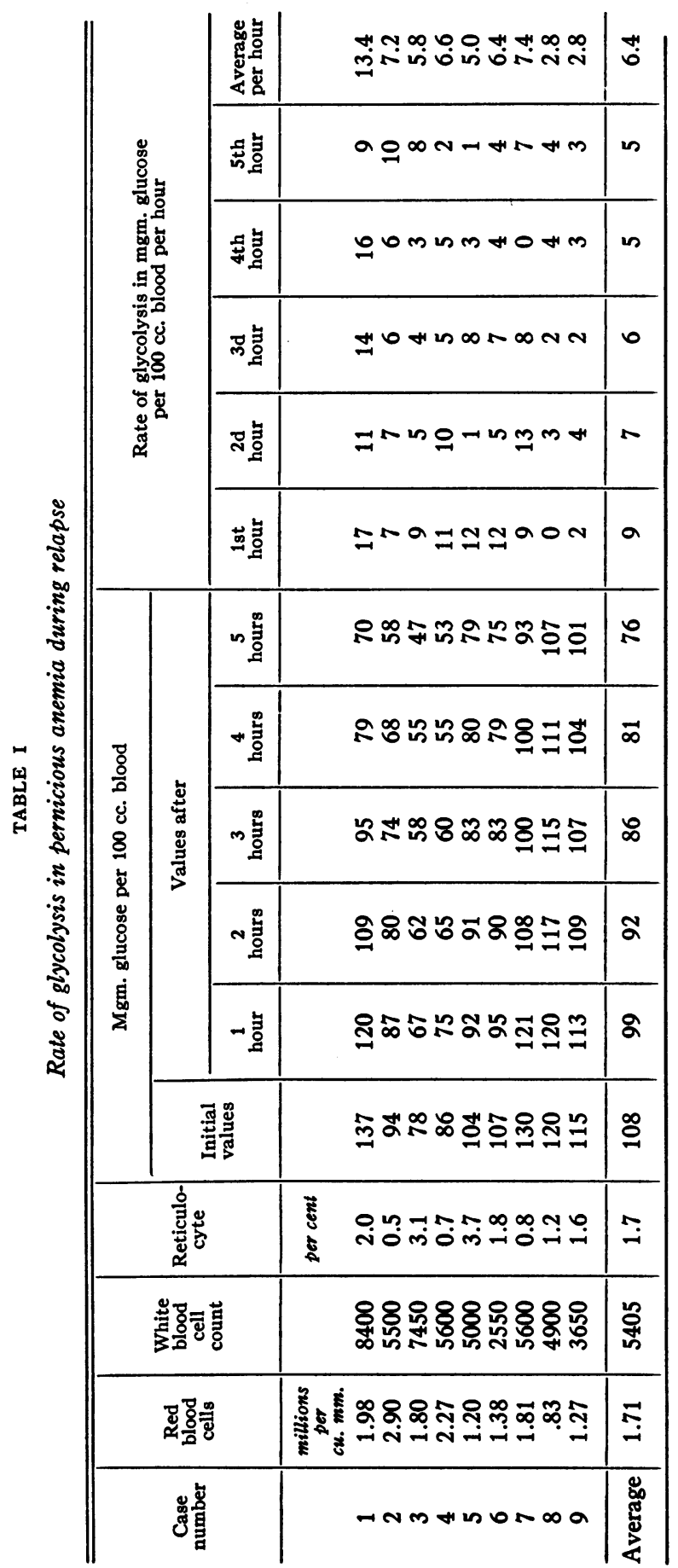


DATA

In Table I are presented the results of the glucose determinations of the blood from 9 cases with pernicious anemia during relapse. The average initial glucose value is $108.0 \mathrm{mgm}$. per $100 \mathrm{cc}$. blood. There is a uniform rate of glycolysis averaging about $6.4 \mathrm{mgm}$. per hour, the limits being 5 to $9 \mathrm{mgm}$. The average rate of glycolysis per hour per million red cells is about $3.7 \mathrm{mgm}$., which is approximately the same as in normal blood.

In Table II are listed the results of the blood sugar determinations of 9 patients with pernicious anemia at the height of the reticulocyte response following ventriculin therapy. The initial average glucose value is $100 \mathrm{mgm}$. per $100 \mathrm{cc}$. blood. The average rate of glycolysis per hour is $10.2 \mathrm{mgm}$., the extremes being 8 to $13 \mathrm{mgm}$. The average rate of glycolysis per hour per million red cells is $5.4 \mathrm{mgm}$. These averages are about 65 per cent more than the glycolytic rate before treatment.

Compared to the standard rate of glycolysis of normal blood as established by Schmitz and Glover (4), and Falcon-Lesses (3), the glycolytic activity of the blood in pernicious anemia during relapse or early remission is markedly retarded. In Chart 1 is a comparison of the average rate of glycolysis of 9 cases with pernicious anemia during relapse and in early remission with normal glycolytic activity as determined by Schmitz and Glover, and Falcon-Lesses.

Although the initial average glucose values in the cases of pernicious anemia were slightly elevated, they remained within the upper limits of normal. Many investigators have pointed out the fact that glycolysis proceeds at a faster rate with a high initial glucose concentration. In view of this, then, the rate of glycolysis in pernicious anemia would be even slower by comparison, since the initial glucose values are higher than those of normal blood. It is further noted that the initial values of the blood sugar determinations of patients with pernicious anemia in early remission are less than those of the patients in relapse, yet the average rate of glycolysis in the former cases is about 65 per cent more. In all instances, glycolysis appears to progress at a fairly uniform rate, averaging 15 to $17 \mathrm{mgm}$. per hour in the normal; 5 to $9 \mathrm{mgm}$. per hour in pernicious anemia during relapse (red blood cell counts from 0.83 to 2.90 millions per cu. $\mathrm{mm}$.); and 8 to $13 \mathrm{mgm}$. per hour in pernicious anemia during early remission (red blood cell counts from 0.80 to 2.90 millions per cu. mm.).

Calculated from figures for normal, the average rate of glycolysis per hour per million red blood cells is about $3.5 \mathrm{mgm}$. In pernicious anemia, the average rate of glycolysis per hour per million red blood cells is $3.7 \mathrm{mgm}$. The decreased rate of glycolysis noted in the blood in anemia as compared to that in the normal blood was definitely proportionate to the decreased number of red blood cells. In the cases of pernicious ane- 


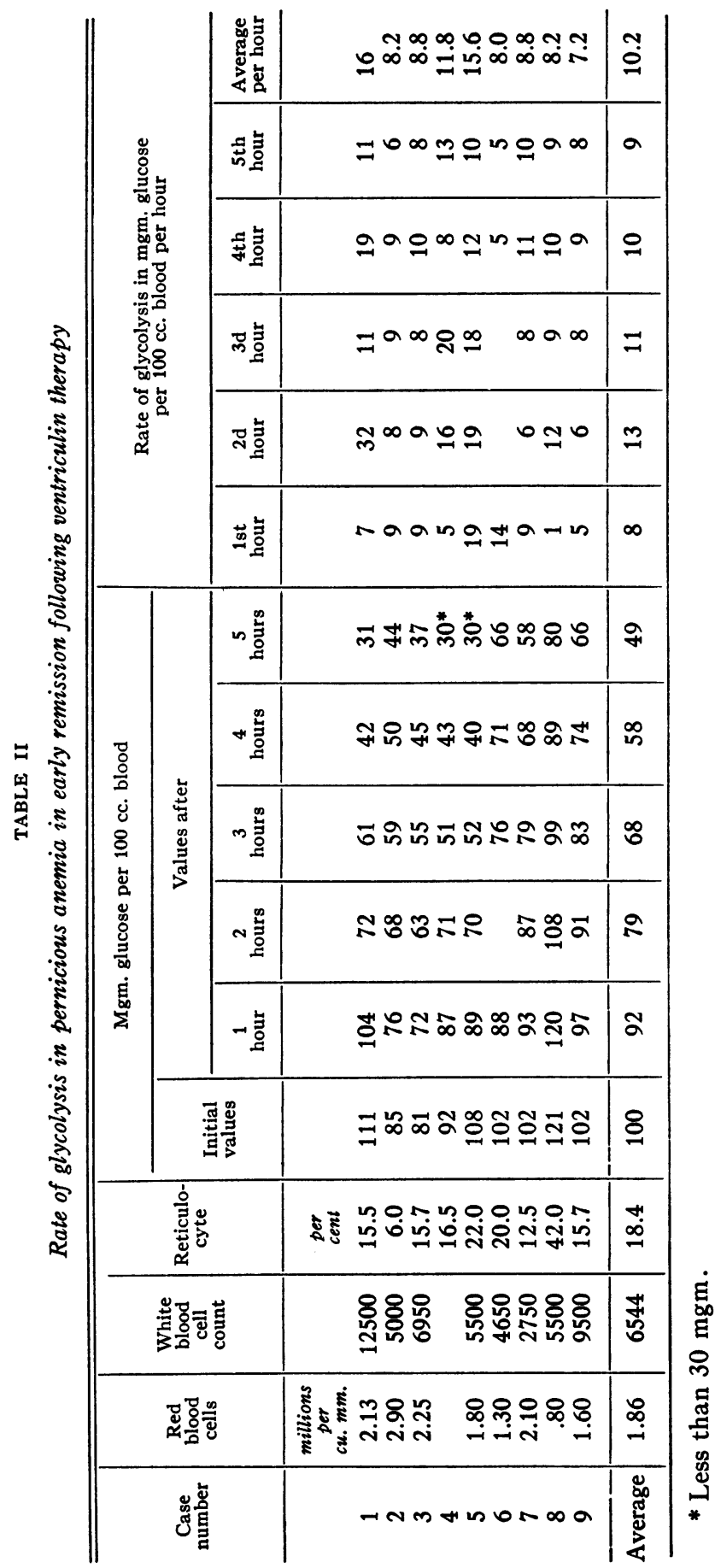


mia in early remission, the blood presents, in addition to a decreased number of red cells, a marked increase in the number and percentage of immature red cells or reticulocytes. The average rate of glycolysis per hour per million red blood cells in this instance is $5.4 \mathrm{mgm}$. Compared to the rate of glycolysis in normal blood there is a decrease proportional to the decreased number of red cells present. However, in comparison to the rate of glycolysis per hour per million red blood cells, in pernicious

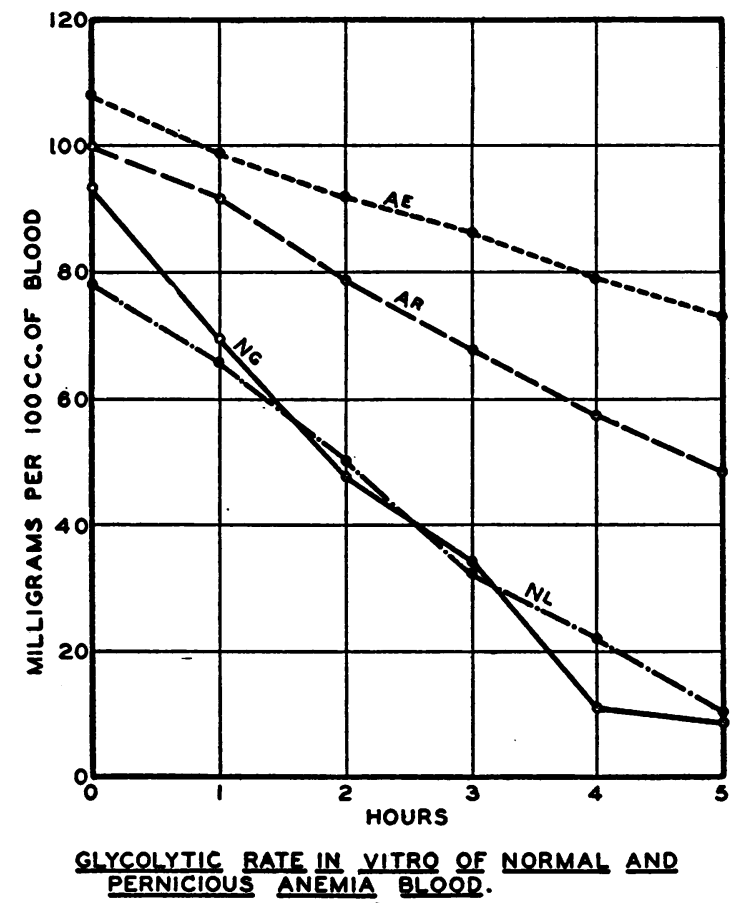

NG = NORMAL OF SCHMITZ - GLOVER -.----17 CASES

$N L=$ NORMAL OF FALCON - LESSES--------6 CASES

$A E=$ PERNICIOUS ANEMIA BLOOD BEFORE

$A R=$ PERNICIOUS ANEMIA BLOOD ATEATMENT - 9 CASES

Chart I

anemia in early remission the glycolytic activity is more rapid than in normal blood. Per unit number of red blood cells (with all factors constant), the only difference between the two is the increased number of reticulocytes. This one factor probably accounts for the accelerated rate of glycolysis which is present in the blood in early remission. As suggested by Barer, Needles and Baldridge (5), this increase in the glycolytic activity may indicate that immature red blood cells have a more active metabolism than adult red blood cells.

Five of the patients had higher red cell counts a week after therapy 
was instituted, two the same, and one less, yet in all instances the rate of glycolysis was faster with the presence of increased numbers of reticulocytes. In Case 6, the rate of glycolysis was determined before therapy, at the height of the reticulocyte response, and after the immature red cells returned to normal numbers. The glycolytic activity was accelerated when the reticulocytes were present in increased numbers, although the red cell count in this instance was the lowest. This is added evidence that the type of cell present is as important as the number of cells.

According to Glover, Daland, and Schmitz (6), there is a difference of $0.004 \mathrm{mgm}$. per hour in the rate of glycolysis with white cell counts showing a variation of 10,000 per cu. $\mathrm{mm}$. In the 9 cases of pernicious anemia, the greatest difference in white cells was 6000 per cu. $\mathrm{mm}$. It would seem that the effect of the white blood cells on the rate of glycolysis in pernicious anemia is extremely small; the glycolytic activity being primarily correlated with the number and type of red cells which were present.

\section{CONCLUSIONS}

1. The average rate of glycolysis per hour in vitro in the blood of 9 cases of pernicious anemia in relapse was $6.4 \mathrm{mgm}$., the range being 5 to $9 \mathrm{mgm}$. at $37^{\circ} \mathrm{C}$.

2. The average rate of glycolysis per hour in the blood of 9 cases of pernicious anemia in early remission was $10.2 \mathrm{mgm}$., the range being 8 to $13 \mathrm{mgm}$. at $37^{\circ} \mathrm{C}$.

3. The average rate of glycolysis per hour per million red blood cells in blood of normal individuals is $3.5 \mathrm{mgm}$.; in pernicious anemia in relapse $3.7 \mathrm{mgm}$.; in pernicious anemia in early remission $5.4 \mathrm{mgm}$. at $37^{\circ} \mathrm{C}$.

4. The retarded rate of glycolysis in pernicious anemia is proportional to the red cell decrease.

5. With all other factors constant, the increase in the rate of glycolysis per hour per million red cells in pernicious anemia in early remission is associated with the increased number of reticulocytes present.

\section{BIBLIOGRAPHY}

1. Maclean, H., and Weir, H. B., Biochem. J., 1915, ix, 412. The Part Played by the Different Blood Elements in Glycolysis.

2. Folin, O., and Wu, H., J. Biol. Chem., 1920, xli, 367. A System of Blood Analysis: Supplement I. A Simplified and Improved Method for Determination of Sugar.

3. Falcon-Lesses, M., Arch. Int. Med., 1927, xxxix, 412. Glycolysis in Normal and in Leukemic Blood.

4. Schmitz, H. L., and Glover, E. C., J. Biol. Chem., 1927, lxxiv, 761. Glycolysis in Leukemic Blood.

5. Barer, A. P., Needles, R. J., and Baldridge, C. W., Proc. Soc. Exper. Biol. and Med., 1929, xxvii, 176. A Study of the Metabolism of Reticulocytes.

6. Glover, E. C., Daland, G. A., and Schmitz, H. L., Arch. Int. Med., 1930, xlvi, 46. The Metabolism of Normal and Leukemic Leukocytes. 